\title{
The Separation of Ownership and Control and Investment Decisions in Mexican Manufacturing Firms
}

\author{
Antonio Ruiz-Porras \\ Department of Quantitative Methods, University of Guadalajara \\ Periférico Norte 799. Núcleo Universitario Los Belenes, 45140. Zapopan, Jalisco, México \\ Tel: (52)-(33)-3770-3300 ext. $5291 \quad$ Fax: (52)-(33)-3770-3300 ext. 5227 \\ E-mail: antoniop@cucea.udg.mx \\ Celina López-Mateo \\ Doctoral Program of Economic and Managerial Sciences, University of Guadalajara \\ Periférico Norte 799. Núcleo Universitario Los Belenes, 45140. Zapopan, Jalisco, México \\ Tel: (52)-(33)-3770 $3300 \quad$ E-mail: celinalm@gmail.com
}

\begin{abstract}
We study how the ownership and control structures may explain investment decisions of Mexican manufacturing firms. We study them with aggregate indexes and the assessment of several regression sets. We use measures of ownership, management and agency costs. The econometric analysis uses longitudinal census data for 182 industries. Our findings support the claim that agency costs, as a measure of the separation of management and control, and firms' size can explain investment decisions. Furthermore the estimations support the necessity to include investment opportunities and cash flow as control variables. The coefficients of all variables are mostly significant and positive.
\end{abstract}

Keywords: Ownership, Control, Investment, Mexico, Manufacturing

\section{Introduction}

Traditional financial management theory explains the behavior of firms in terms of the maximization of value and profits. In practice, such behavior also depends on how the stakeholders determine and control the strategic direction and performance of firms (i.e. corporate governance practices). Particularly, one of the main determinants of how the stakeholders take and execute such decisions is the degree of separation between ownership and control.

The separation between ownership and control occurs due to the asymmetric interests of managers and owners regarding firms' behavior. The separation usually materializes in difficulties to enforce corporate control by the owners. Such difficulties are the so-called agency costs (Ang et al., 2000). This is the reason why agency theory focuses on how the owners can motivate management to pursue owners' goals.

Here we investigate how the separation of ownership and control influences investment decisions on Mexican manufacturing firms. We study them with aggregate indexes and the assessment of several regression sets. Corporate governance studies for emerging economies, like the Mexican one, are scarce. We focus on manufacturing firms because the promotion of their activities has been considered necessary to encourage the development of emerging economies (Nurkse, 1953; Lewis, 1954).

Our study has some distinctive features that differentiate it with respect to other studies. A first feature is that we focus on the effects of the separation of ownership and control in an emerging economy. A second one is that we explicitly introduce the size dimension according to the proposals of Crespi \& Schellato (2007). The last one is that we control for the effects of certain firms characteristics (cash flow and investment opportunities).

This investigation follows several steps. First, we build aggregate indexes of ownership, management and agency costs based on longitudinal census data for the 182 industries that includes the manufacturing sector (INEGI, 2004). Then we estimate several OLS regressions to analyze the determinants of investment for micro, small, medium and large size firms. Finally, we use several statistical tests to check the robustness of our results.

Our findings support the claim that agency costs and the size of firms can explain investment decisions. An increase in operating-expense ratio, a proxy for agency costs, increases fixed capital formation among firms. Furthermore the estimators support the necessity to include the firm's size, investment opportunities and cash flow as explanatory variables. The coefficients associated to such variables are mostly significant and positive. 
The paper is organized as follows. Section 2 reviews the literature. Section 3 describes the methodological design of the research. Particularly it focuses on the description of the data, indicators, model specifications and econometric techniques. Section 4 shows the assessment outcomes. It also includes further statistical estimations and tests to support the empirical assessments. Section 5 discusses the main findings. Section 6 concludes.

\section{Literature review and background}

Here we review the literature relevant for our investigation. First we review the literature that describes the relationships between the separation of ownership and control and agency costs. Then we review some studies that focus on the relationship between corporate governance and investment decisions. Later we focus on recent papers that emphasize the importance of firm size for investment decisions. Finally we review the literature of corporate governance in the context of the Mexican economy.

\subsection{The separation of ownership and control and agency costs}

Traditionally, corporate governance studies assume that the owners of corporations do not have full authority to determine corporate practices. Such lack of control is justified in terms of the asymmetric interests of managers and owners (Berle \& Means, 1932). Indeed, many corporate governance studies, under this assumption, analyze how the separation of ownership and control may affect the decision-making process of the firms.

Theoretically, the separation between ownership and control has been analyzed in terms of the principal-agent framework. Under such framework, corporate decisions and agency costs are explained in terms of the asymmetries of interests of the stakeholders in the firm (Daily et al., 2003). Moreover, an increase in the degree of separation between ownership and control increases agency costs (Ang et al., 2000).

Agency costs are essential to explain the separation between ownership and control. These costs include the ones associated to the risk that the agents will take advantage of the firm for their own benefit. Other costs relate to the resources needed to provide incentives and align the interests of owners and managers. Paradoxically, in spite of their importance, studies that measure these costs only exist since the late 1980`s (McKnight \& Weir, 2009).

The limited evidence regarding agency costs explains why the separation between ownership and control has been recently questioned. Particularly, Cheffins \& Bank (2009), after analyzing various studies conducted between $1930^{\prime}$ s and 1980's among US firms, conclude that corporate governance has never been characterized by such separation. Moreover, they argue that this separation only exists when owners delegate authority on employees.

We believe that further studies regarding the separation between ownership and control must include measures of ownership, management and agency costs. We need such studies to assess the pertinence of the principal-agent framework and to improve our understanding of corporate governance practices. This consideration justifies why in this study we include such measures for empirical purposes.

\subsection{Investment decisions and corporate governance}

Financial economics considers that firms are flows of financial streams that depend on investments (Milgrom \& Roberts, 1992). Such consideration explains why the study of optimal investment decisions and their determinants is an important research field from a financial perspective. Indeed, the long-term performance of firms cannot be understood without understanding their investment decisions.

Some studies suggest that investment decisions depend on corporate governance practices. Andres (2008) argues that high levels of concentration between ownership and control are associated with high levels of investment. He arrives to such conclusion by analyzing panel-data of non-financial German firms. Indeed his findings suggest that efficient investment decisions, low agency conflicts and small information asymmetries occur mainly in family firms.

Syriopoulos et al. (2007) support the importance of the corporate governance processes. Concretely, they find a direct relationship between ownership concentration and market value of Greek firms. In their study, such relationship depends on investment decisions. Moreover, in their study they show how different ownership structures may influence the allocation of firms' resources.

However, some studies do not support the previous claims. Madden (1982) finds that stock market performance, a measure of expected financial streams, is independent of the relative separation of ownership from control. He arrives to such conclusion after comparing the performance of 199 industrial corporations. Thus, according to his findings, at least financial investment may not depend on specific corporate governance practices.

The previous studies show that the nature of the relationship among investment and corporate governance remains unclear. Some studies have analyzed it with qualitative methodologies to gain some insight and further knowledge. Among them, the one of Danielson \& Scott (2007) suggests that overinvestment occurs when firms have 
non-concentrated ownership and control structures. However what seems clear is that further research may be necessary to clarify such relationship.

\subsection{Investment and firm size}

Traditionally, the size of firms is considered an important variable to analyze competitive and behavioral issues. Recently, it has been used to analyze corporate governance issues. Particularly, Crespi \& Schellato (2007) believe that such variable is important to understand the relationships among the degree of concentration of the ownership, control structure and firm investment behavior.

Bøhren et al. (2007) suggest that the size of the firms is necessary to understand corporate governance practices. They find that good practices drive managers to invest and to exert effort to find productive investment projects. Moreover, these practices seem to improve the efficiency of capital allocation in US manufacturing firms. They arrive to such conclusions by controlling cash flow and investment opportunities.

The comparative study of Gugler et al. (2007) confirms the relevance of the size of the firms. They arrive to such conclusion by analyzing the determinants of investment decisions under different corporate governance regimes in Anglo Saxon and European Continental firms. Moreover, their findings suggest that the separation of ownership and control, agency costs and investment decisions are closely related.

The existence of a positive relationship between the size of firm and its levels of investment is explained in terms of the facilities that large firms may have to acquire external funds. However, in spite of this belief, some studies suggest that this claim is not necessarily true, at least for OECD countries (Kadapakkam et al., 1998). Thus, further research seems necessary to clarify the nature of such relationship.

\subsection{Corporate governance in the Mexican economy}

Some economists believe that good corporate governance practices contribute to foster economic growth (Claessens, 2006). Such belief relies on the effects that such practices may on productive investment. Particularly, it is believed that in emerging economies, good corporate governance practices may alleviate the problems associated to the existence of incomplete and imperfect markets and weak institutional frameworks that characterize such economies.

The potential benefits of good corporate practices in emerging economies seem extraordinary. Among other benefits, they could allow access to these economies to external funds, reduce their capital costs, improve the operational performance of their firms and improve the relationships among firms' stakeholders (Claessens, 2006). Indeed the study of corporate governance practices seems a natural research field for development studies.

Paradoxically, most corporate governance studies focus on developed economies, not on emerging ones. Several problems regarding the collection of corporate data in such economies explain such situation. Furthermore the existence of alternative objective functions and behavioral mechanisms among firms complicates further the development of such studies (Allen, 2005). Indeed the literature on these economies, like the Mexican one, is scarce.

In Mexico most corporate governance studies study firms listed in the local exchange market. Such studies are fairly recent and are mainly descriptive. Among them, the one of Castrillo \& San Martin (2007) analyze the structures of ownership and control in family firms. The study concludes that the concentration of such structures reduces principal-agent problems. Theoretically such findings have been explained by Castillo-Ponce (2007).

Ruiz-Porras \& Steinwascher-Sacio (2008) analyze the relationships among corporate governance, diversification strategies and financial performance for a sample of 99 non-financial firms. Their findings show that in firms where property is concentrated there is an orientation toward the domestic market. They also find that there are no trends, regarding strategies and performance, related to the separation between ownership and control.

The previous studies on corporate governance do not focus on manufacturing firms. Moreover, none of them focuses on agency costs, investment decisions or firm size. Indeed, to the best of our knowledge, studies on the relationships among the empirical effects of corporate governance in the manufacturing sector do not exist for Latin American economies. We believe that further research may be necessary, particularly, for development purposes.

\section{Methodology}

Here we describe the methodological design of our investigation. Specifically, we describe the sources of data and the indicators used in the econometric assessments. Furthermore we describe the econometric modeling and testing procedures used to analyze the relationships among the separation of ownership and control, agency costs and investment decisions in Mexican manufacturing firms.

\subsection{Data sources}

We use data from the "Economic Census 2003" reported by the Mexican Bureau of Statistics (INEGI). Such census is constructed accordingly to the North-American-Industry-Classification-System (NAICS). We use a longitudinal 
data set because previous censuses are built with non-comparable methodologies. In Mexico census data are collected every five years. Currently, data for the census collected in 2008 are not available.

Firm-level data are not available due to confidentiality reasons. Here we deal with such constraint by constructing a set of four representative firms for each of the 182 industries included in the census. We build the representative firms accordingly to the number of employees. A micro firm has no more than 10 employees. A small firm has between 11 and 50. A medium firm has between 51 and 250. A large firm has at least 251 employees.

The Mexican census classifies firms of each industry into groups according to the number of employees. The census includes 12 classificatory groups for each of the 182 industries. We do not follow this classification system due to its complexity. We use a simplified one that only includes four groups. The simplified system follows the one of the Mexican Economics Ministry. For comparative purposes, Table 1 shows the relationships between both systems.

We build each representative firm in order to describe the behavior for the representative firm of size " $\mathrm{j}$ " of industry "i". We estimate a weighted variable to assess the effects of the size of the firms according to the classification system proposed by the Mexican Economics Ministry. We use as weight the mean of the number of employees by each type of firm. The representative firm variable is calculated as follows:

$$
\begin{aligned}
& P_{i j t}=\frac{n_{i j t} M_{j t}}{\sum_{t} n_{i j t} M_{j t}} \\
& i=1, \ldots, 182 \\
& j=1,2,3,4 \\
& t=1, \ldots, 12
\end{aligned}
$$

where $P_{\mathrm{ijt}}$ is the weighted indicator of the industry “i”, size " $\mathrm{j}$ ”, group " $t$ "; $\mathrm{n}_{\mathrm{ijt}}$ is the number of firms of the industry "i", size " $\mathrm{j}$ ", group " $\mathrm{t}$ "; $\mathrm{M}_{\mathrm{jt}}$ is the mean of the number of employees of size " $\mathrm{j}$ " in group " $\mathrm{t}$ "; the subindex " $\mathrm{i}$ " refers to the $\mathrm{i}$-th industry; the subindex " $\mathrm{j}$ " refers to the firm of size " $\mathrm{j}$ " (micro, small, medium and large firms); the subindex " $\mathrm{t}$ " refers to the $\mathrm{t}$-th groups included in the size-j classification.

We build representative variables for all the independent and dependent variables. We use the weighted indicator of each one of the four representative firms of industry $i$ to estimate each variable. We multiply $\mathrm{P}_{\mathrm{ijt}}$ by each variable included in the census classification for each one of the twelve groups of firms $\mathrm{V}_{\mathrm{ijt}}$. Such multiplications added accordingly to each subindex " $t$ " provide us with a variable each representative firm of size "j" of the industry " $i$ ".

$$
\begin{aligned}
& \mathrm{RF}_{i j}=\sum_{\mathrm{t}} \mathrm{P}_{\mathrm{ijt}} \mathrm{V}_{\mathrm{ijt}} \\
& \mathrm{i}=1, \ldots, 182 \\
& \mathrm{j}=1,2,3,4 \\
& \mathrm{t}=1, \ldots, 12
\end{aligned}
$$

where $R F_{i j}$ is a variable associated to the representative firm of the industry " $\mathrm{i}$ ", size “ $\mathrm{j}$ ”; $\mathrm{P}_{\mathrm{ijt}}$ is the weighted indicator of the industry "i”", size "j", group " $t$ ".

We should emphasize that the methodological approach developed here allows us to describe the behavior of representative firms. Particularly, it allows us to describe and capture aggregate trends of behavior of firms that belong to a particular industry and size. Representative firm variables are aggregate indexes. Hence the approach does not allow us to analyze the behavior of specific firms.

\subsection{Variables}

Here we describe the main aggregate variables (indexes) used in our econometric study. Particularly, here we use the independent variables as proxies of the ownership and control structures. We follow the proposals of Ang et al. (2000), Bøhren et al. (2007) and Danielson \& Scott (2007) to use such variables. The set of dependent, independent and control variables is summarized in Table 2 .

The set of independent variables includes proxies for the relevance of ownership and management. We follow Bøhren et al. (2007) to build them. We include these indexes for completeness and consistency with traditional corporate governance studies. These variables, in addition to the agency cost ones, aim to capture the effects of the ownership and control structures on investment decisions.

We follow Ang et al. (2000) and Danielson \& Scott (2007) to build the agency cost indexes. We assume that agency costs reflect the degree of separation between ownership and control. We use two alternative measures of agency costs. The first one is the ratio of operating expenses to annual assets (operating-expenses ratio). The second measure is the asset utilization ratio, which is defined as the ratio of annual sales to total assets. 
The agency cost indexes are in reality measures that indicate how effectively the firm's management controls operating costs and deploys its assets. When the operating expenses ratio increases we assume that occur a decrease in efficiency. When the asset utilization ratio increases there is an increase of resources controlled by management. Here we use both proxy measures of agency costs for consistency and completeness with the previous studies.

\subsection{Modeling specification and econometric techniques}

Econometrically, we use a log-linear functional form specification to describe the relationships among ownership, management, agency costs and investment. Such specification allows the regression coefficients to measure the elasticity of investment with respect to each independent variable (determinant). Moreover, the log transformation reduces the possibility of heteroscedasticity problems.

Our assessment approach uses three sets of regressions for comparison purposes. The first set includes the whole set of ownership, management and agency costs measures. The second one includes only the ownership and management ones. The third set includes the agency cost ones. Each set is integrated by four regressions that focus on a specific type of firm (micro, small, medium and large). Thus the model specification set is:

$$
\begin{gathered}
\ln \mathrm{I}_{\mathrm{ij}}=\alpha_{0}+\alpha_{1} \ln \mathrm{O}_{\mathrm{ij}}+\alpha_{2} \ln \mathrm{C}_{\mathrm{ij}}+\alpha_{3} \ln \mathrm{OE}_{\mathrm{ij}}+\alpha_{4} \ln \mathrm{AU}_{\mathrm{ij}}+\alpha_{5} \ln \mathrm{IO}_{\mathrm{ij}}+\alpha_{6} \ln \mathrm{CF}_{\mathrm{ij}}+\alpha_{7} \ln \mathrm{S}_{\mathrm{ij}}+\varepsilon_{\mathrm{ij}} \\
\ln \mathrm{I}_{\mathrm{ij}}=\alpha_{0}+\alpha_{1} \ln \mathrm{O}_{\mathrm{ij}}+\alpha_{2} \ln \mathrm{C}_{\mathrm{ij}}+\alpha_{3} \ln \mathrm{IO}_{\mathrm{ij}}+\alpha_{4} \ln \mathrm{CF}_{\mathrm{ij}}+\alpha_{5} \ln \mathrm{S}_{\mathrm{ij}}+\varepsilon_{\mathrm{ij}} \\
\ln \mathrm{I}_{\mathrm{ij}}=\alpha_{0}+\alpha_{1} \ln \mathrm{OE}_{\mathrm{ij}}+\alpha_{2} \ln \mathrm{AU}_{\mathrm{ij}}+\alpha_{3} \ln \mathrm{IO}_{\mathrm{ij}}+\alpha_{4} \ln \mathrm{CF}_{\mathrm{ij}}+\alpha_{5} \ln \mathrm{S}_{\mathrm{ij}}+\varepsilon_{\mathrm{ij}}
\end{gathered}
$$

where $\mathrm{I}_{\mathrm{ij}}$ is investment; $\mathrm{O}_{\mathrm{ij}}$ is the ownership index; $\mathrm{C}_{\mathrm{ij}}$ represents the management index; $\mathrm{OE}_{\mathrm{ij}}$ is the operating expenses ratio; $\mathrm{AU}_{\mathrm{ij}}$ represents the asset utilization ratio; $\mathrm{IO}_{\mathrm{ij}}$ represents the investment opportunities; $\mathrm{CF}_{\mathrm{ij}}$ is cash flow; $\mathrm{S}_{\mathrm{ij}}$ is the size of the firm; $\varepsilon_{\mathrm{ij}}$ is the random error term.

We use the Ordinary-Least-Squares (OLS) technique to develop the regression analysis. Statistically the OLS technique provides us the best linear unbiased estimators (BLUE) under certain assumptions. Such assumptions include: 1) Linearity of the parameters; 2) Normality, $\left.\varepsilon_{i j} \sim \mathrm{N}\left(0, \sigma^{2}\right) ; 3\right)$ Homoscedasticity, $\left.\operatorname{VAR}\left[\varepsilon_{\mathrm{ij}}\right]=\sigma^{2} ; 4\right)$ $\left.\operatorname{COV}\left[\varepsilon_{\mathrm{ij}}, \mathrm{X}_{\mathrm{i}}\right]=0 ; 5\right)$ No specification bias in the model; and 6) No perfect multicollinearity.

The adequacy of the OLS technique and the robustness of our results are supported with several tests. Concretely, we use pairwise correlation analysis to assess the degree of collinearity among the explanatory variables. In addition, we use Jarque-Bera tests to assess the normality of residuals and Breusch-Pagan tests to detect heteroscedasticity in all the regressions. Furthermore, we use specification-error Ramsey tests to assess the assumptions regarding the functional specification form and to detect omitted-variable bias.

The design of the investigation aims at studying the following hypothesis:

i. Agency costs as a measure of the separation between ownership and control may influence investment decisions.

ii. The size of the firms is necessary to understand corporate governance practices and investment decisions.

iii. Firm and environmental characteristics (cash flow and investment opportunities) may influence investment decisions of Mexican manufacturing firms.

\section{Empirical assessment}

We begin by exploring the correlations between the agency cost proxies and between the ownership and management indexes. Concretely, we use pairwise correlation analysis to assess the degree of collinearity between the operating-expenses and asset-utilization ratios. We also estimate the correlations between the ownership and management indexes. We summarize the statistical results in Table 3.

Table 3 suggests that both measures of agency costs are complementary in the Mexican manufacturing firms. The non significant correlation between both measures of agency costs shows that the degree of multicollinearity is low and that they should be treated as statistically independent. Such correlations do seem to depend on the size of firms. These findings support the functional-specifications forms proposed in equations (3) and (5).

Table 4 reports the regression outcomes for the first set of regressions defined by equation (3). It suggests that ownership and management may be separated among manufacturing firms. In each regression the coefficients associated to both types of measures have opposite signs. Indeed, the outcomes suggest that the relevance of such separation depends on the size of the firms.

Interestingly, the outcomes support the claim that agency costs are necessary to understand corporate governance decisions. Indeed all the coefficients associated to the operating expense ratio index are positive and mostly significant. Moreover the significant coefficients associated to the asset utilization ratio share such positive sign. The interpretation of such findings suggests that an increase in agency costs increases investment among firms. 
Statistically, the estimators support the adequacy of the proposed regression models. In all cases, the $\mathrm{R}^{2}$ estimators are high enough. In addition, the joint significance F-test estimators suggest that all the independent variables are necessary. Furthermore the estimators support the necessity to include the firm's size and cash flow variables as explanatory variables. The coefficients associated to both variables are mostly significant and positive.

Finally, we should point out that the adequacy of the estimations is supported by additional tests. As it known, the OLS method provides efficient estimations when the errors are normally distributed and have homoscedastic variances. In the regression models analyzed here, the Jarque-Bera tests do not reject the null hypothesis of normality. Furthermore the Breusch-Pagan tests do not reject the null hypothesis of homoscedasticity.

Table 5 reports the regression outcomes for the second set of regressions defined by equation (4). It seems to confirm that ownership and management may be separated. Again, the coefficients associated to such measures have opposite signs. Moreover, the outcomes confirm that the size of the firms is important. In medium and large firms, investment increases as long as the proportion of management employees increases.

The estimators support the proposed regression models and confirm our previous findings. Again, the main statistical regression estimators suggest that the independent and control variables are necessary. The coefficients associated to investment opportunities, cash flow and the size of the firm variables are mostly significant and positive. Moreover the Jarque-Bera and Breusch-Pagan tests confirm the adequacy of the estimation method.

Table 6 reports the regression outcomes for the third set of regressions defined by equation (5). It confirms that agency costs are necessary to understand corporate governance decisions. Indeed all the coefficients associated to the operating expense ratio determinant are positive and significant. Interestingly, the results also suggest that the asset utilization ratio may not be a determinant of investment decisions.

The estimators support the proposed regression models and confirm our previous findings. Once more, the statistical regression estimators suggest that the independent and control variables may be necessary to understand investment decisions. Again, the coefficients of the firm variables are mostly significant and positive. Furthermore the Jarque-Bera and Breusch-Pagan tests confirm the adequacy of the estimation method.

The robustness of the regression models is assessed with Ramsey tests. Such tests are used to detect omitted variable-bias and/or incorrect functional forms. Here we use two versions of such test. The first one, the traditional RESET test, uses powers of the estimated independent variable as regressors. The second one uses powers of the RHS variables. The null hypothesis in both versions of the test is that the model is adequately specified (see Table 7).

The Ramsey tests suggest that the regressions for the medium and large firms do not have specification errors. Such conclusion holds with independence of the regression set assessed. However, this is not the case for the regressions used to assess the determinants of investment in micro and small firms. Such finding suggests that the relevance of the ownership and management structures may be questionable under statistical basis.

We summarize our findings by indicating that the evidence supports the claim that agency costs and the size of firms can explain investment decisions. An increase in operating expense ratio increases fixed capital formation among firms. Furthermore the estimators support the necessity to include the firm' size, investment opportunities and cash flow as explanatory variables. The coefficients associated to all variables are mostly significant and positive.

\section{Discussion}

We have assessed the econometric relationships between ownership and control structure with investment decisions in Mexican manufacturing firms from an aggregate perspective. Our findings support the hypotheses that the separation between ownership and control and the size of the firms may influence corporate governance practices and investment decisions. Furthermore, they also support the claim that certain firm and environmental characteristics may influence them.

The findings reported here regarding agency costs and the size of the firm are consistent with other studies. Particularly they are consistent with the ones of Ang et al. (2000) and Danielson \& Scott (2007). The former study finds that the degree of separation between ownership and control (represented by agency costs) has a positive relationship with firm size. The second study provides an explanation on the basis of managerial considerations.

However, we should point out that our findings do no limit themselves to the determination of the significant determinants of investment. They also suggest that the ownership and management control indexes and the asset-utilization ratio are not determinants of investment decisions. Furthermore, they suggest that the econometric modeling structure proposed is adequate mainly for medium and large firms. 
We believe that the specification-error problems in the models for the micro and small firms may occur due to the omission of relevant non-measurable variables. Such belief relies on the qualitative study developed by Ekanem \& Smallbone (2007). In their study they suggest that the intuition, the social networks and the experience of the entrepreneurs may be additional determinants of investment in small firms.

Finally, it is important to emphasize that our empirical methodology allows us to describe and capture trends that occur on representative firms and it is useful only for data that fulfill certain statistical requirements. The violation of some statistical assumptions or the usage of non-aggregated data may modify its usefulness as an analytical tool. Hence, we should recognize that the features of data available define the scope and limits of the methodology and the analysis developed.

\section{Conclusions}

We have studied how the ownership and control structures may explain investment decisions of Mexican manufacturing firms with census data. We have studied them with aggregate indexes and the assessment of several regression sets. We have used measures of ownership, management and agency costs for the 182 industries that integrate the manufacturing sector. The econometric analysis has involved OLS regression techniques and several statistical tests.

The evidence supports the claim that agency costs, as a measure of the separation of ownership and control can explain investment decisions. Particularly we find that an increase in operating expense ratio increases fixed capital formation among firms. Furthermore the estimations support the necessity to include the size of the firms, investment opportunities and cash flow as explanatory variables. The coefficients associated to all variables are mostly significant and positive.

We believe that our investigation provides some ideas for further research. For example, extensions of our study may be used to analyze investment decisions in the financial and non-financial sectors. The "Economic Census 2008", when available, may provide data useful for comparison purposes. Furthermore, our results suggest that further studies on the determinants of investments in micro and small firms in emerging economies may be necessary.

\section{References}

Allen, F. (2005). Corporate governance in emerging economies. Oxford Review of Economic Policy, 21 (2), 164-177.

Andres, C. (2008). Family ownership, financing constraints and investment decisions. University of Bonn, [Online] Available: http://ssrn.com/abstract $=1101453$

Ang, J.S., Cole, R.A. \& Lin, J.W. (2000). Agency costs and ownership structure. The Journal of Finance, 55 (1), 81-106.

Berle, A. \& Means, G. (1932). The modern corporation and private property. New York: Macmillan.

Bøhren, Ø., Cooper, I. \& Priestley, R. (2007). Corporate governance and real investment decisions. European Finance Association, [Online] Available: http://ssrn.com/abstract $=891060$

Castillo-Ponce, R. A. (2007). Entre familia y amigos: La elección de la estructura de la propiedad corporativa. Estudios Económicos, 22 (1), 3-18.

Castrillo Lara, L.A. \& San Martín Reyna, J.M. (2007). La propiedad familiar como mecanismo de gobierno disciplinador de la dirección en las empresas mexicanas: Una evidencia empírica. Contaduría y Administración, UNAM, 222, 59-82.

Cheffins, B. \& Bank, S. (2009). Is Berle and Means really a myth? Business History Review, 83 (3), 443-474.

Claessens, S. (2006). Corporate governance and development. The World Bank Research Observer, 21 (1), 91-122.

Crespi, F. \& Scellato, G. (2007). Ownership structure, financial constraints and investment decisions: Evidence from a panel of Italian firms. University of Turin, [Online] Available: http://ssrn.com/abstract=987996

Daily, C.M., Dalton, D.R. \& Cannella, A.A. (2003). Corporate governance: Decades of dialogue and data. The Academy of Management Review, 28 (3), 371-382.

Danielson, M.G. \& Scott, J.A. (2007). A note on agency conflicts and the small firm investment decision. Journal of Small Business Management, 45 (1), 157-175.

Ekanem, I. \& Smallbone, D. (2007). Learning in small manufacturing firms. The case of investment decision making behavior. International Small Business Journal, 25 (2), 107-129. 
Gugler, K.P., Mueller, D.C. \& Yurtoglu, B.B. (2007). Corporate governance and the determinants of investment. Journal of Institutional and Theoretical Economics, 163 (4), 598-626.

INEGI, Censos Económicos 2004, México.

(2006). Micro, pequeña, mediana y gran empresa. Estratificación de los establecimientos. Censos Económicos 2004, México.

Kadapakkam, P.R., Kumar P. C. \& Riddick, L. A. (1998). The impact of cash flows and firm size on investment: The international evidence. Journal of Banking and Finance, 22 (3), 293-320.

Lewis, W. A. (1954). Economic development with unlimited supplies of labor. Manchester School of Economic and Social Studies, 22 (2), 139-191.

Madden, G.P. (1982). The separation of ownership from control and investment performance. Journal of Economics and Business, 34 (2), 149-152.

McKnight, P.J. \& Weir, C. (2009), Agency costs, corporate governance mechanisms and ownership structure in large UK publicly quoted companies: A panel data analysis. Quarterly Review of Economics and Finance, 49 (2), 139-158.

Milgrom, P. \& Roberts, J. (1992). Economics, organization and management. Englewood Cliffs: Prentice Hall.

Nurkse, R. (1953). Problems of capital formation in underdeveloped countries. Oxford: Basil Blackwell.

Ruiz-Porras, A. \& Steinwascher-Sacio, W.H. (2008). Gobierno corporativo, diversificación estratégica y desempeño empresarial en México. Revista de Administración, Finanzas y Economía, 2 (1), 58-73.

Syriopoulos, T., Tsatsaronis, M. \& Roumpis, E. (2007). Financial decisions, ownership and governance on corporate value. European Finance Association, [Online] Available: http://ssrn.com/abstract=968280

Table 1. The census and the Mexican Economics Ministry classifications for the firms of an industry

\begin{tabular}{|c|c|c|c|}
\hline $\begin{array}{c}\text { Census' Classification of } \\
\text { Firms in the Industry } i \\
(\mathrm{t})\end{array}$ & $\begin{array}{c}\text { Employees in the Firms that } \\
\text { Belong to Group t }\end{array}$ & $\begin{array}{c}\text { Mean of Employees in the } \\
\text { Firms that Belong to Group t } \\
\left(\mathrm{M}_{\mathrm{jt}}\right)\end{array}$ & $\begin{array}{c}\text { Type of Firm According to } \\
\text { the Mexican Economics } \\
\text { Ministry' } \\
\text { classification }\end{array}$ \\
\hline 1 & $0-2$ & 1 & Micro \\
\hline 2 & $3-5$ & 4 & Micro \\
\hline 3 & $6-10$ & 8 & Micro \\
\hline 4 & $11-15$ & 13 & Small \\
\hline 5 & $16-20$ & 25 & Small \\
\hline 6 & $21-30$ & 40 & Small \\
\hline 7 & $31-50$ & 75 & Small \\
\hline 8 & $51-100$ & 175 & Medium \\
\hline 9 & $101-250$ & 375 & Medium \\
\hline 10 & $251-500$ & 750 & Large \\
\hline 11 & $501-1000$ & & Large \\
\hline
\end{tabular}

The table shows the relationships between the Economic Census' classification and the one of the Mexican Economics Ministry. The census classifies firms of each industry into groups according to the number of employees. The census has 12 classificatory groups for each of the 182 industries. The Mexican Economics Ministry' classification for manufacturing firms considers four types. A micro firm has no more than 10 employees. A small firm has between 11 and 50. A medium firm has between 51 and 250. A large firm has at least 251 employees. The mean of employees for the firms of the twelfth group is the average of employees with respect to the total of firms in the twelfth group. 
Table 2. Investment and its determinants (variables)

\begin{tabular}{|c|c|c|}
\hline Variables (Indexes) & Measures & Indicator of the census \\
\hline \multicolumn{3}{|c|}{ Dependent variable } \\
\hline Investment & Fixed capital expenditures & $\begin{array}{l}\text { Gross fixed capital formation } \\
\text { (Value of the fixed assets bought minus the value of the fixed } \\
\text { assets sold) }\end{array}$ \\
\hline \multicolumn{3}{|c|}{ Independent Variables } \\
\hline Ownership & Ownership index & $\begin{array}{l}\text { Ratio of owners, relatives and other employees } \\
\text { non-remunerated to total employees }\end{array}$ \\
\hline Management & Management index & Ratio of management employees to remunerated employees \\
\hline Operating-expenses ratio & Agency costs 1 & Ratio of operating expenses to annual sales \\
\hline Asset-utilization ratio & Agency costs 2 & Ratio of annual sales to total assets \\
\hline \multicolumn{3}{|c|}{ Econometric control variables } \\
\hline Investment opportunities & Ratio of output to capital & Ratio of production value to fixed capital stock \\
\hline Cash flow & Earnings & Net earnings \\
\hline Firm size & Fixed assets & Total value of fixed assets \\
\hline
\end{tabular}

The table shows the variables and indicators used in the econometric assessments. The dependent variable is investment. The independent variables aim to capture the main features of the ownership and control structures. The table includes the definitions of the variables according to the Economic Census of INEGI (Mexican Bureau of Statistics).

Table 3. Correlations between the agency cost variables and between the ownership and management indexes

\begin{tabular}{|l|c|c|}
\hline \multicolumn{1}{|c|}{ Firm Size } & Correlations between agency cost variables & $\begin{array}{c}\text { Correlations between ownership and management } \\
\text { variables }\end{array}$ \\
\hline Micro & 0.0474 & $0.1506^{* *}$ \\
& $(0.526)$ & $(0.0431)$ \\
\hline Small & 0.0858 & $0.7148^{* * *}$ \\
& $(0.2509)$ & $(0.0000)$ \\
\hline Medium & -0.0842 & $0.301^{* * *}$ \\
& $(0.2651)$ & $(0.0000)$ \\
\hline Large & -0.0881 & $0.2719^{* * *}$ \\
& $(0.2503)$ & $(0.0003)$ \\
\hline
\end{tabular}

The estimations use pairwise correlations. The agency cost variables include the asset-utilization and operating-expenses ratios. The ownership and management variables include the ratio of owners to total employees and the ratio of managers to total remunerated employees. Significance levels are given in parenthesis. One, two and three asterisks indicate significance levels of 10, 5 and 1 percent respectively. 
Table 4. Investment decisions and ownership and control structure in Mexican manufacturing firms (OLS regressions - Regressions that include all the independent variables)

\begin{tabular}{|c|c|c|c|c|}
\hline Firm size & Micro & Small & Medium & Large \\
\hline \multicolumn{5}{|c|}{ Regression indicators } \\
\hline Ownership & $\begin{array}{c}0.45^{* * *} \\
(3.21) \\
\end{array}$ & $\begin{array}{c}-0,10 \\
(-1.12) \\
\end{array}$ & $\begin{array}{c}-0.07 \\
(-1.15) \\
\end{array}$ & $\begin{array}{c}-0.06 \\
(-1.02) \\
\end{array}$ \\
\hline Management & $\begin{array}{c}-0.49 * * * \\
(-4.32) \\
\end{array}$ & $\begin{array}{c}0.48^{* * *} \\
(2.90) \\
\end{array}$ & $\begin{array}{c}0.17 \\
(0.66) \\
\end{array}$ & $\begin{array}{c}0.20 \\
(1.20) \\
\end{array}$ \\
\hline Operating-expenses ratio & $\begin{array}{c}0.43 * * \\
(2.28)\end{array}$ & $\begin{array}{c}0.30 \\
(1.10)\end{array}$ & $\begin{array}{l}0.84 * * \\
(1.98)\end{array}$ & $\begin{array}{l}0.67 * \\
(1.91)\end{array}$ \\
\hline Asset-utilization ratio & $\begin{array}{l}0.01^{*} \\
(1.88)\end{array}$ & $\begin{array}{l}0.002 \\
(0.31)\end{array}$ & $\begin{array}{l}0.002 \\
(0.22)\end{array}$ & $\begin{array}{l}0.002 \\
(0.22)\end{array}$ \\
\hline Investment opportunities & $\begin{array}{c}-0.01 \\
(-0.05) \\
\end{array}$ & $\begin{array}{c}0.48^{* * *} \\
(2.68) \\
\end{array}$ & $\begin{array}{c}-0.07 \\
(-0.29) \\
\end{array}$ & $\begin{array}{c}0.67 * * * \\
(3.18)\end{array}$ \\
\hline Cash flor & $\begin{array}{c}0.31 * * * \\
(2.83) \\
\end{array}$ & $\begin{array}{c}0.01 \\
(0.06)\end{array}$ & $\begin{array}{c}0.30^{* * *} \\
(3.30)\end{array}$ & $\begin{array}{l}0.13^{*} \\
(1.85)\end{array}$ \\
\hline Size & $\begin{array}{c}0.48 * * * \\
(3.79)\end{array}$ & $\begin{array}{c}1.09 * * * \\
(9.41)\end{array}$ & $\begin{array}{c}0.66 * * * \\
(5.76)\end{array}$ & $\begin{array}{c}0.83 * * * \\
(9.25)\end{array}$ \\
\hline Constant & $\begin{array}{c}-5.40 * * * \\
(-4.75)\end{array}$ & $\begin{array}{c}-9.93 * * * \\
(-7.09)\end{array}$ & $\begin{array}{l}-4.52 * * \\
(-2.52)\end{array}$ & $\begin{array}{c}-4.37 * * * \\
(-3.77)\end{array}$ \\
\hline Observations & 181 & 181 & 177 & 172 \\
\hline $\mathrm{F}$ & $133.21 * * *$ & $103.82 * * *$ & $36.27 * * *$ & $92.76^{* * *}$ \\
\hline Prob $>F$ & 0.00 & 0.00 & 0.00 & 0.00 \\
\hline $\mathrm{R}^{2}$ & 0.84 & 0.81 & 0.60 & 0.80 \\
\hline Jarque-Bera & 3.25 & 2.86 & 1.99 & 1.34 \\
\hline Prob $>\chi^{2}$ & 0.14 & 0.16 & 0.21 & 0.35 \\
\hline Breusch-Pagan & 5.61 & 2.09 & 4.51 & 0.68 \\
\hline Prob $>\chi^{2}$ & 0.17 & 0.33 & 0.24 & 0.40 \\
\hline
\end{tabular}

The dependent variable is investment. The t-statistics are given in parenthesis. One, two and three asterisks indicate significance levels of 10,5 and 1 percent respectively.

Table 5. Investment decisions and ownership and control structure in Mexican manufacturing firms (OLS regressions - Regressions that include the ownership and management determinants)

\begin{tabular}{|c|c|c|c|c|}
\hline Firm size & Micro & Small & Medium & Large \\
\hline \multicolumn{5}{|c|}{ Regression indicators } \\
\hline Ownership & $\begin{array}{c}0.53 * * * \\
(3.82) \\
\end{array}$ & $\begin{array}{c}-0.09 \\
(-1.02) \\
\end{array}$ & $\begin{array}{c}-0.09 \\
(-1.60) \\
\end{array}$ & $\begin{array}{c}-0.08 \\
(-1.33) \\
\end{array}$ \\
\hline Management & $\begin{array}{c}-0.42 * * * \\
(-3.74)\end{array}$ & $\begin{array}{c}0.55 * * * \\
(3.63) \\
\end{array}$ & $\begin{array}{c}0.35 \\
(1.46) \\
\end{array}$ & $\begin{array}{l}0.28^{*} \\
(1.79) \\
\end{array}$ \\
\hline Investment opportunities & $\begin{array}{c}-0.02 \\
(-0.13) \\
\end{array}$ & $\begin{array}{c}0.55^{* * *} \\
(3.22)\end{array}$ & $\begin{array}{c}-0.11 \\
(-0.46) \\
\end{array}$ & $\begin{array}{c}0.71 * * * \\
(3.35) \\
\end{array}$ \\
\hline Cash flor & $\begin{array}{l}0.21 * * \\
(2.10) \\
\end{array}$ & $\begin{array}{c}-0.07 \\
(-0.91) \\
\end{array}$ & $\begin{array}{c}0.22 * * * \\
(2.68) \\
\end{array}$ & $\begin{array}{c}0.05 \\
(0.83) \\
\end{array}$ \\
\hline Size & $\begin{array}{c}0.57 * * * \\
(4.76) \\
\end{array}$ & $\begin{array}{l}1.15^{* * *} \\
(11.74) \\
\end{array}$ & $\begin{array}{c}0.69^{* * *} \\
(6.12) \\
\end{array}$ & $\begin{array}{c}0.85^{* * *} \\
(9.38) \\
\end{array}$ \\
\hline Constant & $\begin{array}{c}-5.81 * * * \\
(-5.26) \\
\end{array}$ & $\begin{array}{c}-10.23 * * * \\
(-7.59) \\
\end{array}$ & $\begin{array}{l}-4.19^{* *} \\
(-2.33) \\
\end{array}$ & $\begin{array}{c}-3.65 * * * \\
(-3.34) \\
\end{array}$ \\
\hline Observations & 181 & 181 & 177 & 172 \\
\hline $\mathrm{F}$ & $177.53 * * *$ & $145.62 * * *$ & $49.43 * * *$ & $127.69 * * *$ \\
\hline Prob $>F$ & 0.00 & 0.00 & 0.00 & 0.00 \\
\hline $\mathrm{R}^{2}$ & 0.84 & 0.81 & 0.59 & 0.79 \\
\hline Jarque-Bera & 3.55 & 2.96 & 2.29 & 1.47 \\
\hline Prob $>\chi^{2}$ & 0.13 & 0.15 & 0.20 & 0.25 \\
\hline Breusch-Pagan & 7.12 & 1.72 & 4.17 & 0.70 \\
\hline Prob $>\chi^{2}$ & 0.15 & 0.39 & 0.27 & 0.40 \\
\hline
\end{tabular}

The dependent variable is investment. The t-statistics are given in parenthesis. One, two and three asterisks indicate significance levels of 10,5 and 1 percent respectively. 
Table 6. Investment decisions and ownership and control structure in Mexican manufacturing firms (OLS regressions - Regressions that include the agency cost determinants)

\begin{tabular}{|c|c|c|c|c|}
\hline Firm size & Micro & Small & Medium & Large \\
\hline \multicolumn{5}{|c|}{ Regression indicators } \\
\hline Operating-expenses ratio & $\begin{array}{l}0.48 * * \\
(2.45) \\
\end{array}$ & $\begin{array}{c}0.58^{* *} \\
(2.37) \\
\end{array}$ & $\begin{array}{l}0.99 * * \\
(2.52)\end{array}$ & $\begin{array}{l}0.84 * * \\
(2.51) \\
\end{array}$ \\
\hline Asset-utilization ratio & $\begin{array}{l}0.009 \\
(1.17) \\
\end{array}$ & $\begin{array}{l}0.0005 \\
(0.07) \\
\end{array}$ & $\begin{array}{l}0.001 \\
(0.13) \\
\end{array}$ & $\begin{array}{c}-0.00008 \\
(-0.01) \\
\end{array}$ \\
\hline Investment opportunities & $\begin{array}{l}0.28 * * \\
(2.11) \\
\end{array}$ & $\begin{array}{l}0.47 * * \\
(2.57) \\
\end{array}$ & $\begin{array}{c}-0.05 \\
(-0.18) \\
\end{array}$ & $\begin{array}{c}0.67 * * * \\
(3.24) \\
\end{array}$ \\
\hline Cash flor & $\begin{array}{l}0.19^{*} \\
(1.76) \\
\end{array}$ & $\begin{array}{c}0.05 \\
(0.51) \\
\end{array}$ & $\begin{array}{c}0.34 * * * \\
(3.98) \\
\end{array}$ & $\begin{array}{c}0.19 * * * \\
(3.13) \\
\end{array}$ \\
\hline Size & $\begin{array}{c}0.82 * * * \\
(6.82)\end{array}$ & $\begin{array}{c}1.01 * * * \\
(9.25) \\
\end{array}$ & $\begin{array}{c}0.66^{* * *} \\
(5.87) \\
\end{array}$ & $\begin{array}{l}0.77 * * * \\
(11.73) \\
\end{array}$ \\
\hline Constant & $\begin{array}{c}-8.43 * * * \\
(-8.30)\end{array}$ & $\begin{array}{c}-11.10^{* * *} \\
(-8.22)\end{array}$ & $\begin{array}{c}-5.39 * * * \\
(-3.49)\end{array}$ & $\begin{array}{c}-4.65^{* * *} \\
(-4.13)\end{array}$ \\
\hline Observations & 181 & 181 & 177 & 172 \\
\hline $\mathrm{F}$ & $152.68 * * *$ & $138.40 * * *$ & $50.66^{* * *}$ & $129.25 * * *$ \\
\hline Prob $>$ F & 0.00 & 0.00 & 0.00 & 0.00 \\
\hline $\mathrm{R}^{2}$ & 0.81 & 0.80 & 0.60 & 0.80 \\
\hline Jarque-Bera & 3.74 & 2.54 & 1.85 & 1.57 \\
\hline Prob $>\chi^{2}$ & 0.11 & 0.19 & 0.22 & 0.23 \\
\hline Breusch-Pagan & 6.09 & 5.24 & 5.17 & 1.26 \\
\hline Prob $>\chi^{2}$ & 0.13 & 0.22 & 0.23 & 0.38 \\
\hline
\end{tabular}

The dependent variable is investment. The t-statistics are given in parenthesis. One, two and three asterisks indicate significance levels of 10,5 and 1 percent respectively.

Table 7. Specification tests for the regression models

\begin{tabular}{|c|c|c|c|c|}
\hline Firm size & Micro & Small & Medium & Large \\
\hline \multicolumn{5}{|c|}{ Regressions that include all the independent variables } \\
\hline $\begin{array}{l}\text { RESET test } \\
\left(\mathrm{H}_{0} \text { : model has no omitted variables }\right.\end{array}$ & $8.16^{* * *}$ & $6.07 * * *$ & 0.73 & 0.60 \\
\hline Prob $>$ F & 0.0000 & 0.0006 & 0.5330 & 0.6171 \\
\hline $\begin{array}{l}\text { RHS-Ramsey test } \\
\text { ( } \mathrm{H}_{0} \text { : model has no omitted variables) }\end{array}$ & $1.93 * *$ & $1.81 * *$ & 1.20 & 1.39 \\
\hline Prob $>$ F & 0.0126 & 0.0222 & 0.2581 & 0.1336 \\
\hline \multicolumn{5}{|c|}{ Regressions that include the ownership control indexes } \\
\hline $\begin{array}{l}\text { RESET test } \\
\left(\mathrm{H}_{0}: \text { model has no omitted variables }\right.\end{array}$ & $10.45^{* * *}$ & $6.28 * * *$ & 1.15 & 0.87 \\
\hline Prob $>$ F & 0.0000 & 0.0005 & 0.3308 & 0.4594 \\
\hline $\begin{array}{l}\text { RHS-Ramsey test } \\
\left(\mathrm{H}_{0}: \text { model has no omitted variables }\right)\end{array}$ & $2.97 * * *$ & $2.04 * *$ & 1.46 & 1.50 \\
\hline Prob > F & 0.0003 & 0.0156 & 0.1256 & 0.1105 \\
\hline \multicolumn{5}{|c|}{ Regressions that include the agency cost indexes } \\
\hline $\begin{array}{l}\text { RESET test } \\
\left(\mathrm{H}_{0} \text { : model has no omitted variables }\right.\end{array}$ & $11.74 * * *$ & $8.34 * * *$ & 1.03 & 1.02 \\
\hline Prob $>$ F & 0.0000 & 0.0000 & 0.3788 & 0.3840 \\
\hline $\begin{array}{l}\text { RHS-Ramsey test } \\
\text { ( } \mathrm{H}_{0} \text { : model has no omitted variables) }\end{array}$ & $3.32 * * *$ & $2.53 * * *$ & 1.21 & 1.30 \\
\hline Prob $>$ F & 0.0001 & 0.0022 & 0.2698 & 0.2108 \\
\hline
\end{tabular}

This table shows results of specification-form Ramsey test for the three sets of investment-determinant regressions. Here we show shows two versions of such test. The first one, the traditional RESET test, uses powers of the estimated independent variable as regressors. The second one uses powers of the RHS variables. One, two and three asterisks indicate significance levels of 10, 5 and 1 percent respectively. 